\title{
Mathematical Thinking Styles and the Features of Modeling Process
}

\section{Styly myšlení v matematice a charakteristika procesu modelování}

\author{
Juhaina Awawdeh Shahbari ${ }^{1}$ \\ ${ }^{1}$ Al-Qasemi Academy, Israel; juhaina@qsm.ac.il
}

The current study investigated the relationship between students' mathematical thinking style and their modeling processes and routes. Thirty-five eighth-grade students were examined. In the first stage, the students solved questions and, based on their solutions, they were assigned to one of three groups according to their thinking styles, namely visual, analytic and integrative. The focus in the current study was the analytic and visual thinking style; we chose five students from the analytic group and five from the visual group (totaling 10 participants). The analytic group therefore comprised five analytic students, while the visual group comprised the visual students. The two groups engaged in three modeling activities. Findings indicated some differences in the groups' modeling processes while performing the three activities. The primary differences in the modeling processes were manifested in simplifying, mathematizing, and eliciting a mathematical model. Besides, the analytic thinking group skipped the real-model phase in the three activities, while the visual group built a real model for each activity.

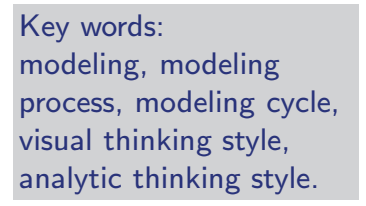

Received 10/2019

Revised 2/2020

Accepted 2/2020

Studie se zabývá vztahem mezi stylem myšlení žáků a procesem modelování. Zúčastnilo se jí 35 žáků osmého ročníku. V první fázi žáci řešili úlohy a na základě jejich řešení byli klasifikovány do jednoho ze tří stylů myšlení: vizuálního, analytického a integrativního. V ohnisku našeho zájmu byl vizuální a analytický styl. Vybrali jsme pět žáků z každé skupiny $(N=10)$, kterým byly zadány tři úlohy vyžadující modelování. Výsledky naznačují rozdíly v modelování mezi oběma skupinami. Hlavní rozdíly se projevily ve zjednodušení, matematizaci a tvorbě matematického modelu. Kromě toho žáci z analytické skupiny přeskočili ve všech úlohách fázi reálného modelu, zatímco žáci z vizuální skupiny reálný model v každé úloze vytvořili.

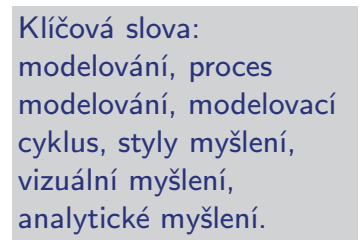

Zasláno $10 / 2019$

Revidováno $2 / 2020$

Prijato $2 / 2020$

\section{Introduction}

Thinking style and cognitive methods strongly affect student performance in many areas determining significant differences, as demonstrated in empirical cognitive psychology studies (e.g. Cakan, 2000; Dwyer \& Moore, 1994). Therefore, students' different thinking styles should be taken into account when determining appropriate educational interventions (Sternberg \& Zhang, 2005). Thus, teacher awareness of different thinking styles is particularly important, specifically when students are solving real-word problems. Ability to solve real-world problems is considered an important goal in mathematics education, as emphasized by the Organization for Economic Cooperation and Development [OECD] (2004). Such problems are the cornerstone of mathematical modeling approach; they offer students the opportunity to meet mathematical and everyday challenges and requirements (Lesh \& Doerr, 2003; Lesh \& Lehrer, 2000; Lesh et al., 2003), and help them understand their world and critically view mathematical information in the sense of active citizenship (Niss, Blum \& Galbraith, 2007). Mathematical modeling is the process of translating between the real world and mathematics (Blum \& Borromeo Ferri, 2009). Knowledge about students' modeling processes can ameliorate their teachers' interventions (Blum \& Leiß, 2005). Given their potential, modeling processes have been studied widely (e.g. English \& Fox, 2005; English \& Watters, 2005; Shahbari \& Daher, 2016; Shahbari \& Peled, 2017; Stillman et al., 2007). However, only a few scholars (e.g. Borromeo Ferri, 2010) have examined the modeling process of individuals having different thinking styles. Furthermore, almost no studies have focused on modeling processes with respect to groups where all modelers have the same thinking style. We chose to examine students that worked in homogenous groups in order to emphasize the thinking style as the main variable. This study aims to shed light on the influence of group thinking style on their modeling process and route while engaged in modeling activities.

Note: This article is an extended and elaborated version of Shahbari, J. A., \& Salameh, R. (2018). Group thinking styles and their modeling process while engaging in modeling activities. In E. Bergqvist, M. Österholm, C. Granberg, \& L. Sumpter (Eds.), Proceedings of the $42^{\text {th }}$ Conference of the International Group for the Psychology of Mathematics Education (Vol. 4, pp. 163-170). PME. 


\section{Framework}

\subsection{Mathematical thinking style}

Thinking style is a way of thinking; it is not an ability, but rather a preferred way of using one's abilities (Sternberg, 1997). Thus, mathematical thinking styles denote how individuals prefer to learn mathematics, not how their mathematical understanding is assessed (Borromeo Ferri, 2010). In addition, it is also indicative of how the individual prefers to proceed with the mathematical task (Sternberg, 1997). Borromeo Ferri and Kaiser (2003) suggested three different thinking styles: the philosopher, who constructs on the basis of concepts; the analyst, who operates within a formula; and the geometer, who has a visual starting point. Similarly, Borromeo Ferri and Kaiser (2003) in their empirical study, suggested three thinking styles: the analytic, the visual, and the integrated. In the current study, we will follow the latter classification, focusing on the visual and the analytic thinking styles. The visual thinking style has been defined as thinking based on the shapes, drawings, and images presented in real situations and relationships (Campbell et al., 1995). Students with a visual thinking style are characterized by a strongly image-oriented way of thinking when solving mathematical problems; this facilitates their obtaining, representing, interpreting, perceiving, and memorizing of information, as well as expressing it (Borromeo Ferri \& Kaiser, 2003).

On the other hand, the analytic style of thinking is identified as thinking symbolically and formalistically (Burton, 2001). Individuals with an analytic thinking style tend to search for structures, patterns or formulas and their application, or to operate on the basis of formulas, as Borromeo Ferri and Kaiser (2003) reported. Analytic thinking involves sorting and separating elements from context, a tendency to focus on the properties of objects and elements for classification into categories, and a preference for using rules about categories and predicting behavior (Monga \& John, 2007). Presmeg (1986) considered the solution of problems with no visual imagery as nonvisual thinking. Some studies reported that students with nonvisual thinking performed better than those with visual thinking (Lean \& Clements, 1981). However, Lowrie and Kay (2001) reported that task difficulty has a significant influence on the way students represent mathematics problems; students typically used visual methods to solve difficult or novel problems, whereas nonvisual strategies were used in less difficult situations. Furthermore, some studies (e.g. Lowrie \& Clements, 2001) indicated that students with a visual thinking style moved toward more nonvisual and analytic forms of reasoning when the familiarity of the tasks increased. Also, Burton (2001) reported that the majority of her interviews indicated that they used a combination of three thinking styles: visual, analytic and conceptual, while they engaged in mathematical tasks.

\subsection{Modeling}

Mathematical modeling means solving complex, realistic, and open problems with the help of mathematics; the process that students develop and use in solving such problems is termed modeling process. The modeling process is cyclic, whereby translating between the real world and mathematics transpires in both directions (Blum \& Borromeo Ferri, 2009). There are multiple modeling processes in the literature; in the current study, we chose the modeling processes suggested by Blum and Leiß (2005), who identified modeling processes from a cognitive perspective as phases and transitions. The phases comprise a situation model, a real model, and a mathematical model, as well as mathematical results and real results. The transitions include several actions: understanding the problem and simplifying a situation model; presenting a real model; mathematizing, which leads to the construction of a mathematical model; applying mathematical procedures; interpreting the mathematical results; and validating, whereby mathematical results are validated in a real-life task. Various visual descriptions of the cyclic-modeling process have been reported in the literature. The current research is based on Blum and Leiß's (2005) modeling cycle. Borromeo Ferri (2007) delineated the modeling process in detail, incorporated the various phases of the modeling cycle on an internal and external level and referred to it as the modeling route. It is important to state that the modeling cycle is considered as an idealized scheme, which does not describe the actual students' process; the way through the modeling process of students through the modeling cycle is identified as the modeling route and it may be different from the modeling cycle (Borromeo Ferri, 2007). The modeling route may not be linear and shift across levels (Maaß, 2006).

\subsection{Modelers with different thinking styles}

Borromeo Ferri (2006) found that the modeling routes depend on students' style of thinking. Reporting about two students with different thinking styles, her analyses indicated that students with an analytic thinking style tend to immediately use the mathematical model, and then may go back to the real model only if there is a need to understand the task better. On the other hand, students with a visual thinking 
style follow the modeling cycle mentioned by Blum and Leiß (2005). In general, Borromeo Ferri (2015) also indicated that when analytic thinkers engage in modeling tasks, they prefer to change the real world model to a mathematical model and work in a formalistic way, while visual thinkers think more in terms of the real world rather than of formal solutions and tend to present their thinking through pictures and graphic drawings.

\subsection{Research aim and question}

Teachers have a central role while their students engage in modeling activities; their knowledge of students' modeling activities will affect their intervention (Blum \& Leiß, 2005). It is important to shed light about the modeling process and routes of students with different thinking styles. The aim of the research is to examine the relationship between two groups of eighth-grade students with different thinking styles and their modeling process and routes while they are engaged in modeling activities. More precisely, this research addressed the following question:

Do groups of students with different thinking styles (visual or analytic) differ in their modeling process and their modeling routes while working on a sequence of modeling activities, and how?

\section{Method}

The current study uses a qualitative approach, focusing on the interpretation of the data which emerged in students' solving process of the tasks in the questionnaire. Students were observed in their classes while they worked on three modeling tasks, which were video recorded.

The research participants and procedure comprised two stages, as detailed below.

\subsection{Research participants, data sources and analysis in the first stage}

This study carried out in a public school. The class chose for the accessibility to conduct the current study and due to the teacher knowledge of modeling approach. For the first stage of the study, 35 students in an eighth-grade class participated; they were almost 14-year-old. The data source was a questionnaire for identifying participants' thinking style.

\subsubsection{Questionnaire}

The study questionnaire comprised eight tasks for classifying students according to their thinking style. Some of these tasks were adapted from other studies (e.g. Lowrie \& Clements, 2001), and some were designed by the researchers. The selected tasks were characterized by a variety of topic areas and of possible solution strategies. Below is an example of two tasks from the questionnaire:

1. Turf Problem (Lowrie \& Clements, 2001): A husband and wife want to turf their backyard (put grass squares down). Before purchasing the turf, they have a ground pool put in their backyard. The pool is $3 \mathrm{~m}$ wide and $5 \mathrm{~m}$ long. Sensibly, they also pave an area $1 \mathrm{~m}$ wide around the pool. If turf costs $\$ 10$ per square meter, how much would it cost to turf the backyard $\left(150 \mathrm{~m}^{2}\right.$ in total $)$ once the pool and the paving are finished?

2. Handshakes task (Kaput \& Blanton, 2001): Five people are at a party. If each person is to shake everybody else's hand once, how many handshakes will take place at the party?

\subsubsection{Data analysis of the questionnaire}

We used the constant comparative method (Glaser \& Strauss, 1967) to analyze the problem-solving processes for each task in the questionnaire for each student. We adopted the categories described by Borromeo Ferri and Kaiser (2003): when illustrating and solving mathematical problems, the visual thinking style was characterized by sketches, drawings, or graphs, while the analytic thinking style was expressed in a formula-oriented way, namely the information from the text of a given problem is expressed by means of a formula. The integrative group was comprised by students who solved some tasks analytically and others visually. An example of students' answers classification for the Turf Problem can be seen below in two tasks. 


\section{a. Turf Problem}

The Visual group's solution:

$$
\begin{aligned}
5 \cdot 7 & =35 \mathrm{~m}^{2} \\
150-35 & =115 \mathrm{~m}^{2} \\
115 \cdot 10 & =1150 \$
\end{aligned}
$$

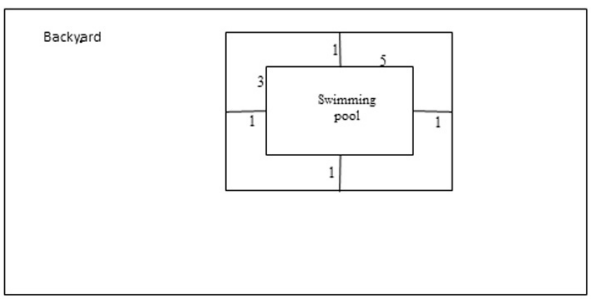

The Analytic group's solution:

$$
\begin{aligned}
3+2 & =5 \mathrm{~m} \\
5+2 & =7 \mathrm{~m} \\
7 \cdot 5 & =35 \mathrm{~m}^{2} \\
150-35 & =115 \mathrm{~m}^{2} \\
115 \cdot 10 & =1150 \$
\end{aligned}
$$

\section{b. The Handshakes task}

The Visual group's solution:

\begin{tabular}{lccccc}
\hline Person & First & Second & Third & Fourth & Fifth \\
Number of shakes & 4 & 3 & 2 & 1 & 0 \\
\hline
\end{tabular}

The Analytic group's solution: The first person shakes hands four times; the second shakes hands three times; the third shakes hands twice and the fourth shakes hands one time. $1+2+3+4=10$.

Based on the styles reflected in solving the questionnaire's tasks, students were then classified into three thinking style groups: analytic (14 students), visual (11 students), and integrated (10 students) thinking style groups.

\subsection{Research participants and data sources in the second stage}

The focus in the current study was the analytic and visual thinking style, so we did not focus on the integrative style thinking. We chose five students from the analytic group and five from the visual group (totaling 10 participants). We selected the 10 students with the assistance of their mathematics teacher in order to maximize matching variables (e.g. gender, mathematics abilities, socioeconomic status). The teacher had 16 years of teaching experience, also had a master's degree in mathematics education and had a knowledge about the modeling approach from her master's studies. Each group included three girls and two boys. All of the students in the two groups are middle socioeconomic status; in each group were two high mathematical abilities students, two middle mathematical abilities students and one low mathematical abilities student. The five analytic students together comprised the analytic group, and the visual students comprised the visual group. Both groups (analytic and visual) were assigned the same three modeling activities in the course of three weeks, with one activity per week. The modeling activities were adapted from the literature (e.g. Blum \& Borromeo Ferri, 2009).

\subsubsection{Video recordings}

Video recordings were made of the two groups working on the three modeling activities and were transcribed.

\subsubsection{Video recording analysis}

We used the constant comparison method (Glaser \& Strauss, 1967) to analyze the students modeling processes in the three modeling activities, taking into account the cognitive aspect of the modelers' modeling cycle (Kaiser \& Stender, 2013). The students' modeling process was elaborated into phases and actions. The modeling processes were described visually according to Shahbari and Tabach's study (e.g. Shahbari \& Tabach, 2018; Shahbari \& Tabach, 2019), in which the researchers visualized all modeling phases and actions of modelers while they engaged in modeling activities. 


\subsection{Sequence of modeling activities}

The sequence includes three modeling activities; the context of these activities is not one of the foci of the current research. The first activity (the Juice Activity, p. 91) adapted from Ben-Chaim, Kerret and Ilany (2012); talking about two boys who are testing four recipes for preparing orange juice to decide which one gives a more "orangey" drink. The second activity (the Been Activity, pp. 116-117) is adapted from Ben-Chaim, Kerret and Ilany (2012). It includes an activity of removing a number of white beans from a bag and replacing brown beans. Then students need to estimate the number of brown beans in the bag that included both white and brown beans. The third activity (the Giant's Shoes) was designed by Blum and Borromeo Ferri (2009). It includes a picture of the sports center in the Philippines in which Florentino Anonuevo Jr. polishes a pair of shoes, with the length and width of the shoes provided, and the students need to estimate the height of the giant that the shoes fit. The main mathematical themes that related to the three activities are ratio and proportion, estimation, and average.

\section{Findings}

First, we will present the modeling processes for the two groups (visual thinking and analytic thinking) while working on the three modeling activities. Then we will focus on their modeling routes and present them visually.

\subsection{Modeling processes between the analytic and visual groups}

The analysis of the modeling processes of the two groups (analytic and visual) in the three activities revealed that each group demonstrated similar features while working on the three modeling activities, but the two groups differed in their modeling processes (phases and actions). Tab. 1 presents the general findings regarding the two groups' modeling processes as well as the phases and the actions that they went through while working on the activities.

Tab. 1: Modeling processes of the analytic and visual groups in the three activities

\begin{tabular}{|c|c|c|c|c|c|c|c|c|c|c|c|c|c|c|c|c|c|c|c|}
\hline \multirow{3}{*}{$\begin{array}{l}\text { Group } \\
\text { Modeling process }\end{array}$} & \multicolumn{10}{|c|}{ Analytic } & \multicolumn{9}{|c|}{ Visual } \\
\hline & \multicolumn{6}{|c|}{ Actions } & \multicolumn{4}{|c|}{ Phases } & \multicolumn{5}{|c|}{ Actions } & \multicolumn{4}{|c|}{ Phases } \\
\hline & 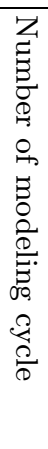 & 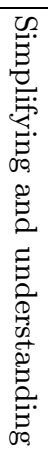 & 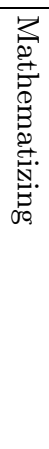 & 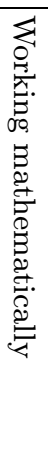 & 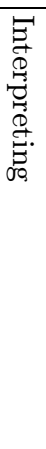 & 总. & 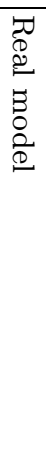 & 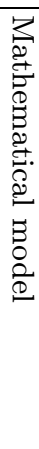 & 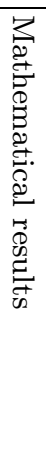 & 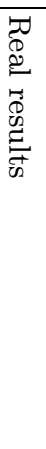 & 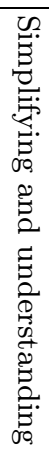 & 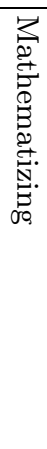 & 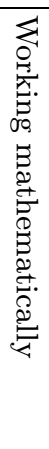 & 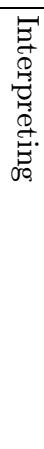 & & 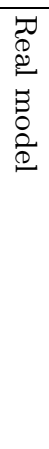 & 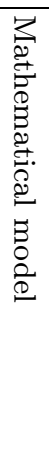 & 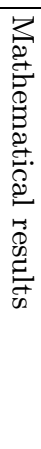 & 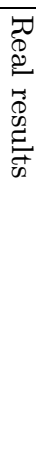 \\
\hline \multirow[t]{3}{*}{ Juice Activity } & 1 & + & + & + & - & - & - & + & + & - & + & + & + & - & - & + & + & + & $\overline{-}$ \\
\hline & 2 & - & + & + & + & + & - & + & + & + & - & + & + & + & + & + & + & + & $\overline{+}$ \\
\hline & 3 & - & + & + & + & + & - & + & + & + & & & & & & & & 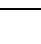 & \\
\hline \multirow[t]{3}{*}{ Been Modeling cycle } & 1 & + & - & + & + & - & - & - & + & + & + & + & + & + & + & + & + & + & $\overline{+}$ \\
\hline & 2 & - & - & + & + & + & - & + & + & + & + & + & + & + & + & + & + & + & + \\
\hline & 3 & - & - & + & + & + & - & + & + & + & & & & & & & & & \\
\hline \multirow[t]{3}{*}{ Giant's Shoes activity } & 1 & + & + & + & - & + & - & - & + & - & + & + & + & - & + & + & + & + & - \\
\hline & 2 & - & + & - & - & - & - & + & - & - & + & + & + & + & + & + & + & + & + \\
\hline & 3 & - & + & + & + & + & - & + & + & + & & & & & & & & & \\
\hline
\end{tabular}

Tab. 1 shows that the major differences between the two groups were in the real model phase. However, finer analyses of the other phases and actions revealed three other main differences in the simplifying and mathematizing actions and in the mathematical model phase. Tab. 2 presents the differences between the two groups, illustrated by sample statements from the students' discussions while working on modeling activities.

As presented in Tab. 2, the main difference between the two groups was the way of illustrating the mathematical ideas. In other words, the same idea was illustrated differently in the two groups. It is important to note that each group have different measures (shoes and height); because of that we have different numbers. 
Tab. 2: Differences in modeling process between analytic and visual groups

\begin{tabular}{|c|c|c|c|c|}
\hline Modeling process & Analytic group & \multicolumn{3}{|c|}{ Visual group } \\
\hline Simplifying & $\begin{array}{l}\text { The simplifying actions occurred through } \\
\text { mathematizing. } \\
\text { Students simplified the situations by } \\
\text { mathematizing, skipping the real model for } \\
\text { the situations. } \\
\text { [5] Student } 2 \text { : We can calculate by ratio } \\
\text { between width and length. }\end{array}$ & \multicolumn{3}{|c|}{$\begin{array}{l}\text { Students simplified the activities by drawing } \\
\text { and illustrating. } \\
\text { [5] Student 1: I can explain the situation; we } \\
\text { have information about... [they drew an } \\
\text { illustration of shoes and body]. } \\
\text { [6] Student 1: We can find the relation } \\
\text { between us and the giants. }\end{array}$} \\
\hline \multirow[t]{5}{*}{ Mathematization } & \multirow[t]{5}{*}{$\begin{array}{l}\text { Students mathematize the situation by } \\
\text { searching for formulas. } \\
\text { [9] Student } 4 \text { : The ratio between the length } \\
\text { and the width ... length } 32 \text { and width } 12 \\
\text { [length and width of their shoes]. } \\
\text { [11] Student } 2: \text { We should simplify the } \\
\text { ratio... } 32: 12 \text {. }\end{array}$} & \multicolumn{3}{|c|}{$\begin{array}{l}\text { Students mathematize the situation by } \\
\text { working in tables and lists. } \\
\text { [10] Student 3: Make a table } \\
\text { [16] Student 3: Your shoes are } 26 \mathrm{~cm} \text {, here I } \\
\text { write } 29 \mathrm{~cm} \text { [in the column of the shoes' } \\
\text { length], your height is } 160 .\end{array}$} \\
\hline & & Height & $\begin{array}{l}\text { Shoes " } \\
\text { length }\end{array}$ & \\
\hline & & 160 & 26 & \\
\hline & & 163 & 30 & \\
\hline & & 146 & 28 & \\
\hline \multirow{6}{*}{$\begin{array}{l}\text { Mathematical } \\
\text { model }\end{array}$} & \multirow{6}{*}{$\begin{array}{l}\text { The mathematical model is presented } \\
\text { through a formula. } \\
H \approx \text { shoes length } \cdot 5\end{array}$} & & & \\
\hline & & Height & $\begin{array}{l}\text { Shoes " } \\
\text { length }\end{array}$ & Ratio \\
\hline & & 160 & 29 & 5.51 \\
\hline & & 163 & 30 & 5.43 \\
\hline & & 155 & 28 & 5.53 \\
\hline & & $\mathrm{X}$ & 5.29 & 5.36 \\
\hline
\end{tabular}

\subsection{Modeling cycles and routes in the analytic and visual groups}

Analysis of the modeling processes of the two groups in the three modeling activities indicated that the analytic group went through more modeling cycles in each activity to obtain the final model than the visual group, as presented in Tab. 1. In addition, the analysis indicated that the analytic group engaged in more skipping during the modeling phases than the visual group. Modeling routes among the two groups in the three modeling activities are presented in Tab. 3.

Tab. 3: Modeling routes of the two group in the three activities

\begin{tabular}{lll}
\hline Activity & Group & Modeling route \\
\hline Juice Activity & Analytic group & See Fig. 1. \\
& Visual group & See Fig. 2. \\
\hline Been Activity & Analytic group & See Fig. 3. \\
& Visual group & See Fig. 4. \\
\hline Giant's Shoes activity & Analytic group & See Fig. 5. \\
& Visual group & See Fig. 6. \\
\hline
\end{tabular}

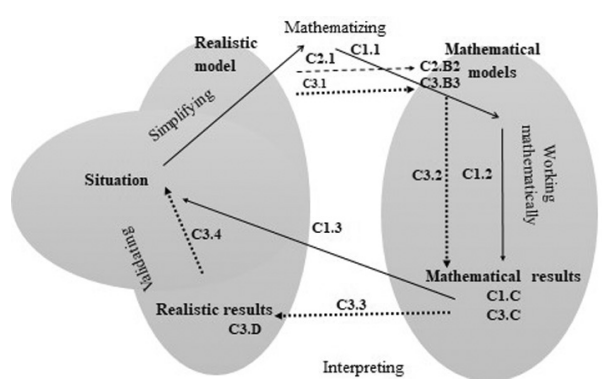

Fig. 1: Modeling routes of the analytic group in the Juice Activity

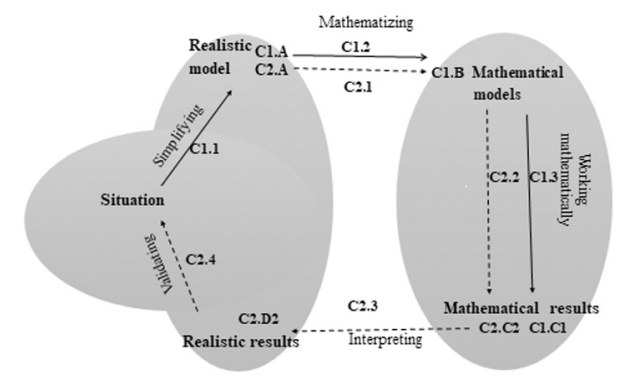

Fig. 2: Modeling cycle of the visual group in the Juice Activity 


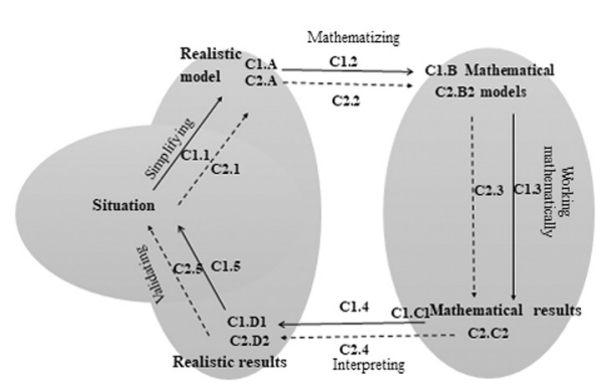

Fig. 3: Modeling routes of the analytic group in the Been Activity

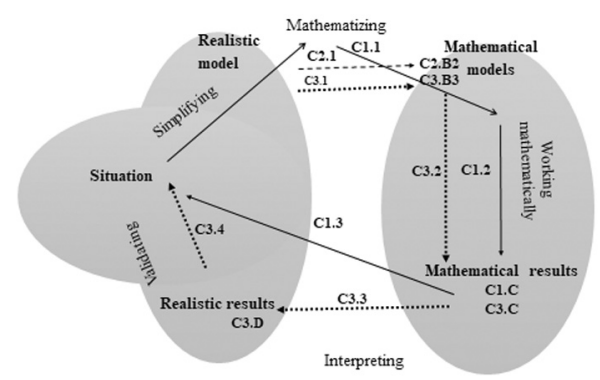

Fig. 5: Modeling routes of the analytic group in the Giant's Shoes Activity

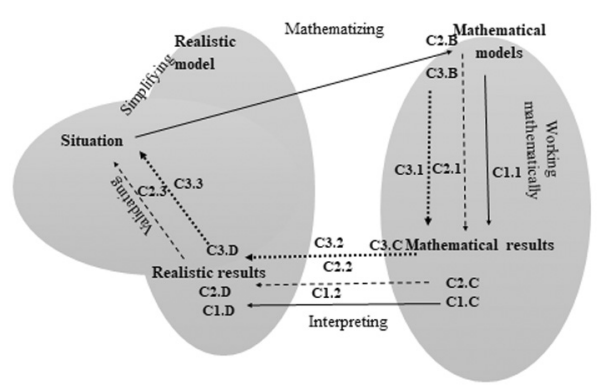

Fig. 4: Modeling cycle of the visual group in the Been Activity

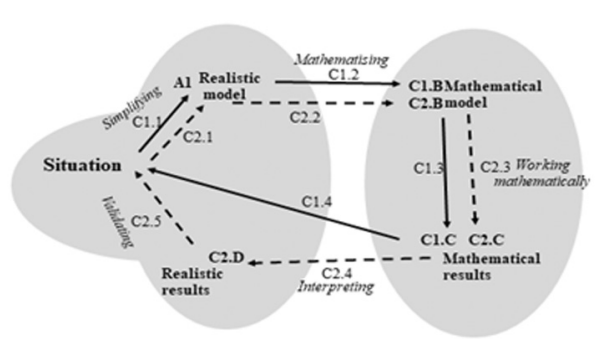

Fig. 6: Modeling cycle of the visual group in the Giant's Shoes activity

Tab. 3 indicates that the analytic group (Fig. 1, 3 and 5) always has three modeling cycles, while the visual group (Fig. 2, 4 and 6) has for the same activities two modeling cycles. In addition, the cycles in the visual group are more sequential than the analytic group. The figures above show that the analytic group always began with the action of mathematizing the activity and did not reach the phase of a real model, while the visual group always began with the action of simplifying the situation and illustrate it with a real model.

For more details, below are the groups' modeling processes for one activity; to avoid repetition, we chose the 'Giant's Shoes' activity:

\section{......}

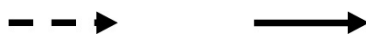

The modeling process of the analytic group in the Giant's Shoes activity, illustrated in Fig. 5, can be split into three modeling cycles: the first cycle, identified by a straight line (C1.1, C1.2, C1.3, C1.4), the second cycle (dashed line) (C2.1, C2.B), and the third cycle, the dotted line (C3.1, C3.B, C3.3, C3.C, C3.4, C3.D, C3.5). Tab. 4 presents the modeling process.

Tab. 4: Modeling process of the analytic group in the Giant's Shoes activity

\begin{tabular}{|c|c|c|}
\hline Modeling cycle & Process & Explanation \\
\hline \multirow[t]{4}{*}{$\underset{\text { First cycle }}{\longrightarrow}$} & C1.1 & $\begin{array}{l}\text { Understanding the situation, simplifying through mathematizing by thinking about } \\
\text { the relation between the width and the length of shoes } 5.29: 2.37\end{array}$ \\
\hline & $\mathrm{C} 1.2$ & $\begin{array}{l}\text { Working mathematically: Finding the ratio between the width and the length of one } \\
\text { student: } 32: 12\end{array}$ \\
\hline & C1.C & Mathematical result: The ratio $8: 3$ \\
\hline & C1.3 & Validating: Not helpful in solving the situation \\
\hline \multirow[t]{2}{*}{ Second cycle } & $\mathrm{C} 2.1$ & $\begin{array}{l}\text { Returning to the situation, simplifying through mathematizing: Finding the ratio } \\
\text { between the length of student's shoes and her height. }\end{array}$ \\
\hline & $\mathrm{C} 2 . \mathrm{B}$ & Mathematical model: The height of person is four times the length of their shoes. \\
\hline \multirow[t]{7}{*}{$\begin{array}{l}\text { Third cycle } \\
\end{array}$} & C3.1 & $\begin{array}{l}\text { Returning to the situation, simplifying through mathematizing: Finding the ratio } \\
\text { between the average length of their shoes. }\end{array}$ \\
\hline & C3.B & Mathematical model: The height of a person is five times the length of shoes \\
\hline & C3.2 & Applying the model: $5.29 * 5$ \\
\hline & C3.C & Mathematical result: the height of the giant is 26.45 . \\
\hline & C3.3 & Application to reality: it is almost $27 \mathrm{~m}$ \\
\hline & C3.D & Realistic result: $27 \mathrm{~m}$ \\
\hline & C3.4 & Validating the results in the situation: $27 \mathrm{~m}$ \\
\hline
\end{tabular}


The visual group in the Giant's Shoes activity, illustrated in Fig. 6, engaged in two modeling cycles. The group began by simplifying the situation through the use of a drawing; they tried to draw an image of shoes through their simplification to yield a real model (A) and thought about the numerical relationship between the giant's height and the length of his shoes, and how this relation would be equivalent for ordinary people (C1.1); they began mathematizing by ordering their own shoe length and height measurements, and the ratio between these measurements was recorded on a table they constructed (C1.2); they then elicited a mathematical model, indicating that the ratio between the length of the shoes and the height resembled the ratio of their own measures (C1.B); they applied the results (C1.3), and each student received mathematical results resembling their ratio. They received different results because each had a different ratio (C1.C); thus, these results did not resolve the problem (C1.4). The second cycle began with a mathematical model, comprising the average of the group's ratio calculations (C2.B); they applied it (C2.3) and received the numerical result of 32 (C2.C); this result was then transformed into a realistic result, indicating the giant's height as $32 \mathrm{~m}$ (C2.D); they accepted this result (C2.5).

\section{Discussion}

The aim of the current study was to examine the relationship between two group of eighth-grade students with different thinking styles (analytic and visual) and their modeling process and routes while they engaged in a sequence of modeling activities. The findings revealed that each group had similar features among the three modeling activities, while there were major differences in the two groups' modeling processes. The main difference between the two groups was in the action directly after reading the situation, through the simplifying process and the ability to access the activity. The analytic group tried to simplify the three activities by mathematizing them, while the visual group tried to simplify the activities by drawing and illustrating the situations. These findings are in line with Borromeo Ferri's (2015), who indicated that when analytic thinkers deal with a modeling activity they preferred to change the real-world situation to a mathematical model and operate in a formalistic manner, while visual thinkers think more in terms of the real world rather than of formal solutions, and thus tend to present their thinking by means of pictures and drawings. We can conclude that students with a visual thinking style make more connections between mathematics and the real world by starting with simplification and using a real model; these results are similar to the findings of Huang (2013) who reported that students with a visual thinking style make more connections between mathematical concepts and the physical world.

The findings also revealed differences in the mathematizing action and in the illustration of the mathematical model. The analytic group emphasized the use of formulas, while the visual group mathematized with the help of lists, tables and drawings; the same features of action were identified in mathematical models. The features of the mathematizing actions of the analytic group when they were engaging in modeling activities were found to be similar to features activated in solving routine world problems. In fact, as Borromeo Ferri and Kaiser (2003) reported, students with an analytic thinking style are more likely to search for structures, patterns, or formulas and their application, or to operate with formulas.

According to the modeling cycles and routes, we identified that the modeling routes of the analytic group are longer than the visual group's. However, the analytic group engaged in more skipping of the modeling phases; in the three activities, they skipped the real model, while the visual group always addressed this phase. It is important to note that skipping modeling phases or actions did not relate to the effectiveness of the elicited models, as emphasized by Shahbari and Tabach (2016).

The findings also indicated that each group had the same features in the three activities. However, we did not have an indicator of whether the groups would have continued to work in a similar way and maintained the same features of the modeling routes, had the sequence of the modeling activities been longer. Researchers reported that changes can occur; for example, Kaiser (2007) reported that expert modelers control their solving strategies and therefore achieve their aim faster.

Finally, Sternberg (1997) proposed that understanding thinking styles help teachers to differentiate instruction to maximize the learning outcomes of all learners; in our case, teachers' awareness of students' thinking styles has an essential role in designing effective interventions while students engaged in modeling activities. The findings emphasized that students' thinking style didn't relate to their mathematical abilities, due to that the two groups worked and used different modeling routes even when they obtained final mathematical models with parallel contents; therefore, the teachers need to be aware of different preferences in simplifying and in mathematizing situations. Teachers also should be aware of presenting and modeling solution strategies in visual and analytic ways. More spastically, teachers should be aware that students with different thinking style prefer to simplify, mathematize and elicit mathematical models in a different way; being aware of the difference can make teachers conscious of their intervention. Besides 
our conclusion, we must indicate about the limitation of the current study, it conducted among only two groups the visual and the analytic groups and without the group of integrated thinking style students. Also, the number of participants was too small to address the research questions adequately or to generalize the results beyond the three activities which included in the current study. We suggest expanding our work by examining more than a single group from each style, and with including the integrated thinking style students, to learn more about modeling processes and modeling routes of students with different thinking styles and the features of each thinker.

\section{References}

Ben-Chaim, D., Keret, Y., \& Ilany, S.-B. (2012). Ratio and proportion: Research and teaching in mathematics teachers' education (Pre- and in-service mathematics teachers of elementary and middle school classes). Sense Publisher.

Blum, W., \& Borromeo Ferri, R. (2009). Mathematical modeling: Can it be taught and learnt? Journal of Mathematical Modeling and Application, 1(1), 45-58.

Blum, W., \& Leiß, D. (2005). "Filling Up" - the problem of independence-preserving teacher interventions in lessons with demanding modeling tasks. In M. Bosch (Ed.), Proceedings of the fourth congress of the European Society for Research in Mathematics Education (CERME 4) (pp. 1623-1633). Sant Feliu de Guíxols, Spain, Fundemi IQS Universitat Ramon Llull.

Borromeo Ferri, R. (2006). Theoretical and empirical differentiations of phases in the modeling process. $Z D M$, 38(2), 86-95. https://doi.org/10.1007/bf02655883

Borromeo Ferri, R. (2007). Modeling problems from a cognitive perspective. In C. P. Haines, P. Galbraith, W. Blum, \& S. Khan (Eds.), Mathematical modeling (ICTMA12): Education, engineering and economics (pp. 260-270). Horwood Publishing Limited.

Borromeo Ferri, R. (2010). On the influence of mathematical thinking styles on learners' modeling behavior. Journal fur Mathematik-Didaktik, 31(1), 99-118. https://doi.org/10.1007/s13138-010-0009-8

Borromeo Ferri, R. (2015). Mathematical thinking styles in school and across cultures. In S. Cho (Eds.), Selected regular lectures from the 12th International Congress on Mathematical Education (pp. 153-173). Springer. https://doi.org/10.1007/978-3-319-17187-6_9

Borromeo Ferri, R., \& Kaiser, G. (2003). First results of a study of different mathematical thinking styles of schoolchildren. In L. Burton (Ed.), Which way in social justice in mathematics education? (pp. 209-239). Greenwood.

Burton, L. (2001). Research mathematicians as learners - and what mathematics education can learn from them. British Educational Research Journal, 27(5), 589-599. https://doi.org/10.1080/01411920120095762

Campbell, K. J., Collis, K.F., \& Watson, J. M. (1995). Visual processing during mathematical problem solving. Educational Studies in Mathematics, 28(2), 177-194. https://doi.org/10.1007/BF01295792

Cakan, M. (2000). Interaction between cognitive styles and assessment approaches. In LSU Historical dissertations and theses. https://digitalcommons.lsu.edu/gradschool_disstheses/7145

Dwyer, F. M., \& Moore, D. M. (1994). Effect of colour coding and test type (visual/verbal) on students identified as possessing different field dependence levels. British Journal of Educational Technology, 25(3), 217-219.

English, L. D., \& Fox, J. L. (2005). Seventh-graders' mathematical modeling on completion of a three-year program. In P. Clarkson et al. (Eds.), Building connections: Theory, research and practice (Vol. 1, pp. 321-328). Deakin University Press.

English, L. D., \& Watters, J. J. (2005). Mathematical modeling in the early school years. Mathematics Education Research Journal, 16(3), 58-79. https://doi.org/10.1007/BF03217401

Huang, C.-H. (2013). Engineering students' visual thinking of the concept of definite integral. Global Journal of Engineering Education, 15(2), 111-117.

Glaser, B. G., \& Strauss, A.L. (1967). Discovery of grounded theory: Strategies for qualitative research. Aldine Publishing Company.

Kaiser, G. (2007). Mathematical modeling at schools how to promote modeling competencies. In C. P. Haines, P. Galbraith, W. Blum, \& S. Khan (Eds.), Mathematical modeling (ICTMA12): Education, engineering and economics (pp. 110-119). Horwood Publishing Limited.

Kaiser, G., \& Stender, P. (2013). Complex modeling problems in co-operative, self-directed learning environments. In G. A. Stillman, G. Kaiser, W. Blum, \& J. P. Brown (Eds.), Teaching mathematical modeling: Connecting to research and practice (pp. 277-294). Springer. https://doi.org/10.1007/978-94-007-6540-5_23 
Kaput, J. J., \& Blanton, M. (2001). Algebrafying the elementary mathematics experience: Part 1: Transforming task structures. In H. Chick, K. Stacey, J. Vincent, \& J. Vincent (Eds.), Proceedings of the 12th International Commission on Mathematics Instruction Study Conference (pp. 344-351). University of Melbourne, Melbourne, Australia.

Lean, G., \& Clements, M. A. (1981). Spatial ability, visual imagery, and mathematical performance. Educational Studies in Mathematics, 12(3), 267-299. https://doi.org/10.1007/BF00311060

Lesh, R., \& Doerr, H. M. (2003). Foundations of models and modeling perspective on mathematics teaching, learning, and problem solving. In R. Lesh, \& H. M. Doerr (Eds.), Beyond constructivism: Models and modeling perspectives on mathematics problem solving, learning, and teaching (pp. 3-33). Erlbaum.

Lesh, R., Hoover, M., Hole, B., Kelly, A., \& Post, T. (2000). Principles for developing thought-revealing activities for students and teachers. In R. Lesh, \& A. Kelly (Eds.), Handbook of research design in mathematics and science education (pp. 591-645). Lawrence Erlbaum.

Lesh, R., \& Lehrer, R. (2003). Models and modeling perspectives on the development of students and teachers. Mathematical Thinking and Learning, 5(2-3), 109-129. https://doi.org/10.1080/10986065.2003.9679996

Lowrie, T., \& Clements, M. A. (2001). Visual and nonvisual processes in grade 6 students' mathematical problem solving. Journal of Research in Childhood Education, 16(1), 77-93. https://doi.org/10.1080/02568540109594976

Lowrie, T., \& Kay, R. (2001). Relationship between visual and nonvisual solution methods and difficulty in elementary mathematics. The Journal of Educational Research, 94(4), 248-255.

https://doi.org/10.1080/00220670109598758

Maaß, K. (2006). What are modeling competencies? ZDM, 38(2), 113-142. https://doi.org/10.1007/BF02655885

Monga, A. B., \& John, D. R. (2007). Cultural differences in brand extension evaluation: the influence of analytic versus holistic thinking. Journal of Consumer Research, 33(4), 529-536. https://doi.org/10.1086/510227

Niss, M., Blum, W., \& Galbraith, P. (2007). Introduction. In W. Blum, P. L. Galbraith, H.-W. Henn, \& M. Niss (Eds.), Modeling and applications in mathematics education (pp. 3-32). Springer.

Organization for Economic Cooperation and Development (OECD). (2004). Learning for tomorrow's world: First results from PISA 2003. OECD.

Presmeg, N. C. (1986). Visualization in high school mathematics. For the Learning of Mathematics, 6(3), 42-46.

Shahbari, J. A., \& Daher, W. (2016). Mathematical models' features: Technology and non-technology. European Journal of Science and Mathematics Education, 4(4), 523-533.

Shahbari, J. A., \& Peled, I. (2017). Modeling in primary schools: Constructing a conceptual system and making sense of fractions. International Journal of Science and Mathematics Education, 15(2), 371-391.

https://doi.org/10.1007/s10763-015-9702-x

Shahbari, J. A., \& Tabach, M. (2016). Different generality levels in the product of a modeling activity. In C. Csikos, A. Rausch, \& J. Szitanyi (Eds.), Proceedings of the $40^{\text {th }}$ Conference of the International Group for the Psychology of Mathematics Education (Vol. 4, pp. 179-186). PME.

Shahbari, J. A., \& Tabach, M. (2018). Developing prospective mathematics teachers' knowledge of the modeling approach. Scientia in educatione, 9(2), 146-158. https://doi.org/10.14712/18047106.1183

Shahbari, J. A., \& Tabach, M. (2019). Adopting the modeling cycle for representing prospective and practicing teachers' interpretations of students' modeling activities. In G. Stillman, \& J. Brown (Eds.), Lines of inquiry in mathematical modeling research in education (pp. 179-196). ICME-13 Monographs, Springer.

https://doi.org/10.1007/978-3-030-14931-4_10

Sternberg, R. J. (1997). Thinking styles. Cambridge University Press.

Sternberg, R. J., \& Zhang, L.-F. (2005). Styles of thinking as a basis of differentiated instruction. Theory into Practice, 44(3), 245-253. https://doi.org/10.1207/s15430421tip4403_9

Stillman, G., Galbraith, P., Brown, J., \& Edwards, I. (2007). A framework for success in implementing mathematical modeling in the secondary school. In J. Watson, \& K. Beswick (Eds.), Proceedings of the 30th Annual Conference of the Mathematics Education Research Group of Australasia (MERGA) (Vol. 2, pp. 688-697). MERGA. 